\title{
The role of ecophysiological studies in the genus Prosopis: implications for the conservation of drought-prone species
}

\author{
Rol de los estudios ecofisiológicos en el género Prosopis: implicaciones para la \\ conservación de especies propensas a sequía
}

Felipe S. Carevic ${ }^{1}$

\begin{abstract}
The genus Prosopis is widely distributed in various agroforestry ecosystems, primarily in semiarid and arid climates of the Americas, Asia and Africa. These species serve as the food source for a large number of animal communities, such as goats and sheep, which consume their seeds and flowers. The seeds are also used to produce various products including flour and pulp. In northern Chile some species of Prosopis are threatened, which supports the inclusion of these species in reforestation plans. One critical source of information in the formulation of such reforestation strategies is the physiological analysis of these populations and the effects of abiotic factors on parameters such as reproduction and growth in the Prosopis forests of the Atacama Desert. In this note, we analyze the importance of ecophysiological studies of Prosopis populations and the main strategies adopted by these plants in response to water scarcity, which are critical to the survival of these desert communities. Future research must investigate these variables to provide an improved understanding of the endogenous behavior of species of Prosopis, which will be instrumental for creating forestation plans that will regenerate and preserve these woodlands.
\end{abstract}

Key words: desert agrosystem; Prosopis; ecophysiology; northern Chile.

\section{RESUMEN}

El género Prosopis se distribuye ampliamente en diversos ecosistemas agroforestales, principalmente en climas áridos y semiáridos de América, Asia y África. Estas especies poseen un rol fundamental como fuente de alimento para un gran número de comunidades de animales, como cabras y ovejas, las que consumen directamente sus semillas y flores. Asimismo, sus frutos también se utilizan para producir diversos productos, incluyendo harina y pulpa. En el norte de Chile, algunas especies del género Prosopis están en categoría de conservación amenazada, hecho que apoya la inclusión de estas especies en diversos planes de reforestación. Una fuente importante de información para la formulación de dichas estrategias de reforestación, es el análisis fisiológico de estas poblaciones y los efectos de los factores abióticos en parámetros como la reproducción y el crecimiento de los bosques de Prosopis del desierto de Atacama. En este artículo se destaca la importancia de los estudios ecofisiológicos en poblaciones del género Prosopis y se analizan las principales estrategias adoptadas por estas comunidades vegetacionales en respuesta a la escasez de agua, hechos que resultan fundamentales para la supervivencia de estas comunidades en zonas áridas. Futuras investigaciones debieran abordar estas variables para proporcionar una mejor comprensión de la conducta endógena de las especies del género Prosopis, hecho que será fundamental para la creación de planes de forestación para regenerar y preservar estos bosques.

Palabras clave: agroecosistema de desierto; Prosopis; ecofisiología; norte de Chile.

\section{Introduction}

The genus Prosopis is widely distributed in Asia, Africa and arid and semi-arid regions of the Americas, from the southwestern United States to central Chile and Argentina (CONAF, 1997). Prosopis agroforestry systems have been traditionally profitable, providing a large range of products derived from the seeds of its species (Alvarez and Villagra, 2009). In the Atacama Desert, Prosopis species are particularly important since they can provide a native system that contributes to the ecological and socio-economic stability of farmers. The Pampa del Tamarugal ecosystem, located in a hyperarid zone of northern Chile, is a vast, arid plain with salty and sandy soils. The center of this ecosystem is located at $19^{\circ} 33^{\prime} \mathrm{S}$ and $22^{\circ} 15^{\prime} \mathrm{W}$ in the Atacama Desert (Tarapacá Region, northern Chile) and is the driest desert in the world (Carevic et al., 2012). The Pampa del Tamarugal ecosystem is the

\footnotetext{
1 Facultad de Recursos Naturales Renovables. Universidad Arturo Prat, Iquique, Chile. Campus Huayquique.

* Corresponding author: felipe.carevic@unap.cl
} 
endemic area of distribution of Prosopis tamarugo Phil. and other species of the same genus (P. alba, $P$. burkartii and $P$. strombulifera). According to data from the closest weather station to the area (Canchones), the summer season has absolute minimum temperatures near $7{ }^{\circ} \mathrm{C}$, whereas the winter season (June-August) has absolute minimum temperatures of $-5{ }^{\circ} \mathrm{C}$ (Table 1). The atmospheric humidity has extreme maximum values between 70 and 80 percent during the summer and between 80 and 95 percent during the winter. The areas of Chile that are most populated by Prosopis are the Pampa del Tamarugal (Iquique, I Region), with an area of 20,000 ha of Prosopis tamarugo and Prosopis alba, and ecosystems of Regions II and IV (CONAF, 1997). In the Pampa del Tamarugal, the great majority of these woodlands were planted during repopulation efforts undertaken by the Corporación de Fomento in the 1960s after the species suffered declines in their populations; these woodlands are protected by the Corporación Nacional Forestal at the Pampa Del Tamarugal National Reserve (CONAF, 1997).

Environmental governmental institutions in Chile have classified some species as endangered due to declines in their populations. However, the species Prosopis burkartii is of particular concern among environmentalists due to the recent change in its conservation status to critical, with no more than 50 individuals remaining (Ministerio de Medio Ambiente, 2011). This status requires the attention of researchers of northern Chile to address the need for information regarding the physiological and

Table 1. Mean rainfall and mean of minimum and maximum temperatures at the Pampa del Tamarugal agroforestry system in northern Chile.

\begin{tabular}{lccc}
\hline \multirow{2}{*}{ Month } & \multicolumn{3}{c}{ 1970-2013 period } \\
\cline { 2 - 4 } & $\begin{array}{c}\text { Mean Rainfall } \\
(\mathrm{mm})\end{array}$ & $\mathrm{T}_{\text {min }}$ & $\mathrm{T}_{\text {max }}$ \\
\hline January & 0.1 & 19.2 & 32.6 \\
February & 0 & 15.4 & 34.2 \\
March & 0 & 16.3 & 31.3 \\
April & 0 & 17.4 & 31.5 \\
May & 0 & 17.7 & 28.8 \\
June & 0 & 15.6 & 29.3 \\
July & 0 & 18.3 & 25.0 \\
August & 0 & 18.5 & 26.8 \\
September & 0 & 19.1 & 29.4 \\
October & 0 & 24.8 & 27.1 \\
November & 0 & 22.2 & 28.3 \\
December & 0.3 & 18.8 & 30.3 \\
\hline
\end{tabular}

ecological characteristics of this species and the difficulty in locating its populations. Furthermore, the mining industry, specifically of non-metallic elements, in the Tarapacá Region requires large amounts of water for leaching processes. The water is obtained from the Pampa del Tamarugal groundwater and may play an important role in the decline of this species (Oyarzún and Oyarzún, 2011). The region has also experienced increased migration of its human inhabitants, mainly because of the lack of economic development projects that incorporate the sustainable use of natural resources in the area (Carevic, 2008). Traditionally, seed production in species of the genus Prosopis played an instrumental role in the formation and equilibrium of the agroforestry system in the desert in Tarapacá and other areas prone to water stress, as these seeds form part of the diet of goats and sheep (Campos et al., 2011). The analysis of abiotic characteristics on physiological traits of Prosopis species in hyperarid agroforestry systems such as the Atacama Desert could provide a useful strategy for farmers and researchers to sustain yields in the long term. The present study describes the importance of ecophysiological studies for Prosopis conservation and illustrates how these data could be useful in reforestation plans.

\section{Ecophysiological studies as tools of conservation}

The genus Prosopis exhibits high genetic variability at the intra- and inter-population levels, which may influence its capacity to respond to extrinsic factors such as weather, forestry activities or edaphological parameters (Cony, 1996). These characteristics, in addition to producing different physiological responses by these species, induce differences in the amount of protein in their seeds, their level of sugar concentration and biomass production (Cony and Trione, 1998). One of the most sensitive characteristics to environmental stress is stem diameter growth, which explains why population comparisons of species of this genus at different altitudinal gradients revealed differences in growth response according to the environmental conditions encountered (Villagra et al., 2005). A thorough study of the stem growth of desert agroforestry species and their relation to environmental factors is of great importance. This study will allow us to improve the sustainable management of these 
species through a better understanding of their development and evolution over time and to model more effectively the growth-weather relations in ecosystem and dynamic forestry models (Martin et al., 2010). Similarly, detailed knowledge of the relation between stem growth and environmental factors in Prosopis will enable us to develop a better understanding of the role that these species play as $\mathrm{CO}_{2}$ fixers and to perform simulations on how these species grow under different scenarios of climate change, which will aid in the development of reforestation plans (Martín et al., 2010). Additionally, there is no general consensus that explains the low natural regeneration rates of individuals of the genus Prosopis (Carevic et al., 2012). Previous studies have concluded that regeneration rates are extremely low, mainly due to periods in which the ENSO (El Niño-Southern Oscillation) phenomenon is active, which induces erratic behavior in the natural germination of seeds (López et al., 2006). During the ENSO phenomenon it appears that the main physiological trait that supports plant survival is deeper root growth (Squeo et al., 2007). However, other factors that might affect regeneration rates are of an ecological nature, such as predation pressure from herbivores or competition with grasses associated with the agroforestry ecosystems of Prosopis (Weltzin et al., 1998). Thus, one cause of the low regeneration rates of these species might be the high number of negative ecological interactions involved in their reproductive cycles, such as the presence of herbivores and competition with other plants for nutrients.

\section{Key strategies in response to environmental stress}

Winter frosts, extreme temperatures and atmospheric humidity are recurring factors in desert climates during most parts of the year, and these factors must be taken into consideration when evaluating growth and seed production in species subjected to xeric climates and other drought-prone regions (Delatorre et al., 2008). Groundwater levels have a substantial influence on growth variables of phreatophyte species such as Prosopis. However, the effect of environmental variables such as temperature or atmospheric humidity on the physiological parameters of xerophytes is a subject of ongoing study. These variables might have an equal or even greater impact than water availability on the growth traits of species in arid regions, as these abiotic parameters influence seed production, stem growth and root development (Cony et al., 1998; Squeo, 2007). Thus, it is important to investigate the effects of these environmental factors on the reproductive and growth capacities of species of Prosopis and the strategies used by individuals to respond to these stresses. This information will be important for accurate predictions of environmental stress or climate change scenarios that might affect desert agroforestry ecosystems (Magrin et al., 1997). Stresses caused by drought and frosts lead to the dehydration of plant cells, which might have a direct impact on the reproductive behavior of species in arid and semiarid climates (Villagra et al., 2010). Furthermore, the resistance strategies of plants in arid and semi-arid climates involve certain morphological and physiological characteristics that may be common, such as osmotic adjustment. Defensive systems against drought stress involve changes in gas exchange, leaf area, the opening of stomata and osmotic adjustment (Delatorre et al., 2008; Lehner et al., 2001; Villagra et al., 2010).

The xylem has been described as the main channel for transporting water and nutrients from the roots to the crown, and traditionally parameters relating to gas exchange such as stomatal conductance have been reported as the main factors regulating water flux (Sperry, 2011). Water tension in the xylem depends greatly on the resistance to flux, which is determined partly by the physical structure of the xylem. If that tension increases substantially, the water column being transported will experience embolisms that can disrupt water conductance (Sperry, 2011). The morphology of the leaves, phenotypic plasticity and osmotic adjustment in Prosopis seem to be prevailing factors affecting the vulnerability of the xylem to cavitation. Thus species of this genus that present the typical physiological features for resistance to drought, such as low osmotic potential in full turgor and low average vessel diameter, will have greater capability to resist or survive xylem cavitation during frost or water stress periods (López et al., 2013).

\section{Seed production}

Another key aspect of reproduction and growth is the energy-saving strategies or masting resources that species of this genus use during periods of 
environmental stress. Seed production is one of the main links between trees and soil, and it plays a key role in nutrient cycling in agroforestry ecosystems. One of the most important research questions pertaining to species living in agroforestry systems in arid zones-and species of the genus Prosopis in general-focuses on their inter-annual seed production and stem diameter growth and the extent to which these variables are influenced by ecophysiological variables. Species living in areas with some level of stress commonly adopt ontogenic behavior or energy trade-offs that ensure the viability of their populations. Thus some species living in drought-prone climates tend to suppress their growth to enhance seed production, such as Quercus ilex, which suffers from water stress during very dry years, This strategy is reflected in the negative correlations observed between these two parameters (Sánchez-Humanes et al., 2011). In contrast, years with high humidity show positive correlations between these parameters, indicating a balanced strategy that allows growth and seed production simultaneously (Koenig et al., 1994). This behavior has not yet been observed in species living in desert climates. The most relevant data come from studies of Prosopis caldenia and Prosopis flexuosa conducted in Argentina. Pisani and Distel (1998) found that in response to herbivory $P$. caldenia exhibited increased thorn growth, which decreased the phenol concentration in its leaves. A study that thoroughly analyzes the existence of trade-offs between reproduction and growth variables in Prosopis would greatly clarify the possible presence of biennial or masting resource phenomena in species adapted to xeric climates that exhibit high inter-annual variability in seed productivity. Such a study would also provide useful information for management and conservation models integrating tree growth and seed production and the interaction between these two processes (Dalmasso and Anconetani, 1993).

\section{Summary and Conclusions}

In hyperarid areas such as the Atacama Desert, which exhibits low net primary production as a result of extremely low rainfall levels of $0.6 \mathrm{~mm}$ per year, extreme temperatures that favor high rates of evaporation and frosts during the winter, agricultural strategies must take into account and manage Prosopis populations in situ. This approach will enable farmers to improve the economic profitability of livestock production and the exploitation of plants of this genus for medicinal and gastronomic uses while contributing to the conservation of these species. The main objective of future projects in the desert forest of northern Chile should be to contribute to the sustainable management of Prosopis communities by developing a greater understanding of the functioning of these ecosystems and predicting their responses to global climate change. The most important productive activities of these communities, including seed production, pollen emission and stem growth, must also be considered when developing a management plan. There is a lack of information about the influence of inter- and intraannual ecophysiological factors on Prosopis species occupying arid native and reforested woodlands. Understanding these variables will facilitate the selection of individuals for optimal seed production for reforestation projects and foster sustainable development in agroforestry areas where Prosopis species are distributed. Furthermore, economic and social uses of the results of such studies must be based on the understanding that these woodlands support the people who inhabit and interact with them through the resources they provide and the ways in which they transform the landscape.

\section{Acknowledgments}

The authors wish to thank Corporación Nacional Forestal for their support. This article was funded by Fondecyt project $\mathrm{N}^{\mathrm{o}} 11130242$.

\section{Literatura Citada}

Alvarez, J.A.; Villagra, P.E.

2009. Prosopis flexuosa DC. (Fabaceae: Mimosoideae). Kurtziana, 35 (1): 49-63.

Campos, C.; Campos, V.; Mongeaud, A.; Borghi, C.; De los Ríos, C.; Giannoni, S.

2011. Relationships between Prosopis flexuosa (Fabaceae) and cattle in the Monte desert: Seeds, seedlings and saplings on cattle-use site classes. Revista Chilena de Historia Natural, 84: 289-299.

Carevic, A.

2008. Los campesinos del desierto chileno. Editorial Universidad Arturo Prat, 222 pp.

Carevic, F.; Carevic, A.; Delatorre. J.

2012. Historia natural del género Prosopis en la región de Tarapacá. Idesia 30: 113-117. 
Carevic, F.; Carmona, E.; Muñoz-Pedreros, A.

2014. Seasonal diet of the burrowing owl Athene cunicularia Molina, 1782 (Strigidae) in a hyperarid ecosystem of the Atacama desert in northern Chile. Journal of Arid Environments, 97: 237-241.

\section{CONAF.}

1997. Plan de manejo Reserva Nacional Pampa del Tamarugal. Ministerio de Agricultura. 138 pp.

Cony, $\mathrm{M}$.

1996. Genetic variability in Prosopis flexuosa D.C., a native tree of the Monte phytogeographic province, Argentina. Forest Ecology and Management, 87: 41-49.

Cony, M.; Trione, $\mathrm{S}$.

1998. Inter- and intra- specific variability in Prosopis flexuosa and P. chilensis: seed germination under salt and moisture stress. Journal of Arid Environments, 40: 307-317.

Dalmasso, A.D.; Anconetani, J.

1993. Productividad de frutos de Prosopis flexuosa (Leguminosae), algarrobo dulce, en Bermejo, San Juan. Multequina, 2: 173-181.

Delatorre, J.; Pinto, M.; Cardemil, L.

2008. Effects of water stress and high temperature on photosynthetic rates of two species of Prosopis. Journal of Photochemistry and Photobiology B, 92: 67-76.

Koenig, W.; Knops, H.; Carmen, W.; Stanback, M.; Mumme, R. 1994. Estimating acorn crops using visual surveys. Canadian Journal of Forest Research, 24: 2105-2112.

Lehner, G.; Delatorre, J.; Lutz, C.; Cardemi, L.

2001. Field Studies on the Photosynthesis of two desert chilean plants Prosopis chilensis and Prosopis tamarugo. Journal of Photochemistry and Photobiology B, 64: 36-44.

López, B.C.; Rodríguez, R.; Gracia, C.; Sabaté, S. 2006. Climatic signals in growth and its relation to ENSO events of two Prosopis species following a latitudinal gradient in South America. Global Change Biology, 12: 897-906.

López, D.; Fernandez, M.; Verga, A.

2013. Drought stress tolerance of Prosopis chilensis and Prosopis flexuosa species and their hybrids. Trees Structure and Function, 27: 285-296.

Magrin, G.; Gay García, C.; Cruz Choque, D.; Giménez, J.C.; Moreno, A.R.;. Nagy, G.J; Nobre, C.; Villamizar, A.

2007. Latin America. Climate Change 2007: Impacts, Adaptation and Vulnerability. In: Contribution of Working Group II to the Fourth Assessment Report of the Intergovernmental Panel on Climate Change, Parry, M.L; Canziani, O.F; Palutikof, J.P.; van der Linden, P.J; Hanson, C.E. Eds., Cambridge University Press, Cambridge, UK, pp. 581-615.
Martin, D.; Carevic, F.; Vazquez-Piqué, J.; Alejano, R.

2010. Does acorn production influence the diametric stem growth of holm oak? World Dendro 2010. 8th International Conference on Dendrochronology. Rovaniemi, Finlandia.

Ministerio de Medio Ambiente

2011. Acta Sesión No 05 Octavo proceso clasificación de especies, http://www.mma.gob.cl/clasificacionespecies/ Anexo_octavoproceso/DS_19_2012MMA_OCTAVOProceso_ Diario_Oficial_11feb2013.pdf. Accessed 01 June 2014.

Oyarzún, J.; Oyarzún, R.

2011. Sustainable development threats, inter-sector conflicts and environmental policy requirements in the arid, mining rich, northern Chile territory. Sustainable Development, 19: 263-274.

Pisani, J.G.; Distel, R.A.

1998. Inter- and intraspecific variations in production of spines in Prosopis caldenia and Prosopis flexuosa. Journal of Chemical Ecology, 24: 23-36.

Sánchez-Humanes, B.; Sork, V.; Espelta, J.

2011. Trade-offs between vegetative growth and acorn production in Quercus lobata during a mast year: the relevance of crop size and hierarchical level within the canopy. Oecologia, 166: 101-110.

Sperry, J.S.

2011. Hydraulics of vascular water transport. In: Wojtaszek, P., ed., Signalling and communication in plants: mechanical integration of plant cells and plants. Springer, Berlin. Germany, pp 303-327.

Squeo, F.A.; Holmgren, M.; Jiménez, M.; Albán, L.; Reyes, J.; Gutiérrez, J.

2007. Tree establishment along an ENSO experimental gradient in the Atacama Desert. Journal of Vegetation Science, 18: 193-200.

Villagra, P.E.; Boninsegna, J.; Alvarez, J.; Cony, M.; Cesca, E.; Villalba, R.

2005. Dendroecology of Prosopis flexuosa woodlands in the Monte desert: implications for their management. Dendrochronologia, 22: 209-213.

Villagra, P.E.; Vilela, A.; Giordano, C.; Alvarez, J.

2010. Ecophysiology of Prosopis species from the arid lands of Argentina: what do we know about adaptation to stressful environments? In: Desert Plants, Ramawa,t K.G. (Ed.). Springer-Verlag. USA. pp 321-340.

Weltzin, J.F.; Archer, S.; Heitschmid, R.

1998. Defoliation and woody plant (shape Prosopis glandulosa) seedling regeneration: potential vs realized herbivory tolerance. Plant Ecology, 138: 127-135. 
